\title{
Factors Negatively Affect Speaking Skills at Saudi Colleges for Girls in the South
}

\author{
Mona. M. Hamad ${ }^{1}$ \\ ${ }^{1}$ Department of English Language, College of Science \& Arts, Almajardah, King Khalid University, Saudi \\ Arabia \\ Correspondence: Mona. M. Hamad, Department of English Language, College of Science \& Arts, Almajardah, \\ King Khalid University, Saudi Arabia. Tel: 966-542-349-145. E-mail: monahamed65@hotmail.com
}

Received: September 2, 2013 Accepted: September 22, 2013 Online Published: November 5, 2013

doi:10.5539/elt.v6n12p87 URL: http://dx.doi.org/10.5539/elt.v6n12p87

\begin{abstract}
This study investigated factors negatively affect English language speaking skills in Saudi colleges for girls in the South in terms of: a) Instructors. b) Students. c) Curriculum and textbook. d) English Language teaching methods and exercises. e) Teaching and learning environment. To collect data for the study, a questionnaire papers were distributed to 150 students studying at Mhayeal and Almajardah colleges of King Khalid University (KKU) at English languages department, and 10 female instructors were interviewed about the students' questionnaire information. Data generated were subjected to descriptive and analytical approach using SPSS. The findings were: 1. Using Arabic in class affect students' proficiency. 2. Students fear speaking English Language in public and can't make a phone conversation, presentation in English without Arabic translation. 3. Curriculum of listening and speaking does not contain enough exercises for speaking skills. 4. Instructors do not use strategies that develop speaking such as: role-play, debates, and presentation - assignment. 5. More time is devoted to listening skills than speaking skills. 6. Labs are not used for teaching listening and speaking skills. 7. Rarely CD is used as speaking model. 8. More than 30 students are in listening and speaking class. It has been strongly recommended: 1. Prohibit the students from using Arabic in English Language classes. 2. Use motivating teaching strategies such as: cultural debatable topics, discussions, role-play, and presentations assignment to develop speaking proficiency. 3. Teach Listening and speaking course in the lab. 4. Increase the time of listening and speaking course to six hours instead of three to develop speaking proficiency. 5. Activate English club and societies inside the colleges. 6. Students' number in listening and speaking class must not exceed 30 .
\end{abstract}

Keywords: factors, negatively, affect

\section{Introduction}

Chinese Proverb "Learning is a treasure that will follow its owner everywhere." English as Foreign Language (EFL) or English as Second Language (ESL) is taught in all Arab countries to graduate students and individuals with good competence of English skills to help them communicate in their societies and European countries as well. Wattereson M. (2008) has stated that, the international use of English as a Lingua Franca (ELF) - i.e. between non - native speakers of different nationalities, in situations where no native English speakers are present - has become an important feature of business, diplomacy, education, and personal relationships around the world. Judith Munat (2005) stated English today is considered as the international lingua franca and, according to some estimates, is spoken (at various levels of competence) by more than 2,000 million people around the globe, including native speakers (over 380 million) and those who learn it as a second or foreign language. It is the language of air and maritime navigation, of the worldwide web and of diplomacy, as well as the vehicle for international scientific exchange, and its pervasive presence can be felt in pop culture and the worldwide media. English Club the world's premier showed how learning any language involves the four skills which we call "Macro Skills" that we need for complete communication. When we learn our native language, we usually learn to listen first, then to speak, then to read, and finally to write. These are called the four "language skills". (listen $\rightarrow$ speak) (read $\rightarrow$ write). Each two skills are connected to each other in other words. Listening and reading are the input "reception" while speaking, and writing are the output "production". This rule is the same with learning English. Unfortunately in many schools as well as in universities in Saudi Arabia less attention is 
given to speaking skills. Students can get high marks in grammar tests and reading comprehension, but they find themselves at a loss when they asked to deliver a speech in front of their colleagues in class, they also hesitate when they happen to get in touch with native speakers of English out the class. Saudi girl - students always find difficulties to communicate using English Language. Since, speaking English language is very important these days to communicate with the world markets of different fields. This study aims at investigating the factors that negatively affect English language speaking skills in Saudi colleges for girls in terms of: instructors, students, curriculum and textbook, English Language teaching methods and exercises, and teaching and learning environment to come out with recommendations for ameliorating the gab of speaking skills, by investigating English students and instructors at Mhayeal and Almajardah colleges of King Khalid University (KKU) at English languages Department, as a sample of the study.

\section{Literature Review}

God gives us two eyes to input skills of reading to come out with writing skills, and give us two ears to input listening skills to come out with speaking skills. So we have double ability for reception (read and listen) to come out with perfect production (write and speak). Speaking skills are regarded a very important and unique skills, it is the first output of any language and the only skill which you need partner to practice, you can listen to audio resource alone, you can read a book alone, you can write a letter alone, but you can't speak alone, you need someone to speak to. Learning speaking ESL/EFL skills highly depends on classroom lessons and language - labs. Speaking skills depends on the first skill "listening". Speaking is regarded a very important skill, however many students lack it. (Sherwin Cody 2011, P. 6) has stated if there is a subject of really interest and utility, it is the art of writing and speaking one's own language effectively. It is the basis of culture as we all know; but it is infinitely more than that; it is the basis of business. No salesman can sell anything unless he can explain the merits of his good in effective English among people. English language is a global language but the students refuse to interact using it in the lecture room as (Fahad 2013, p. 84) reveals in his study that: "Saudi students find it inappropriate to speak in class because of their fear to be seen as verbally challenging their teachers' views openly and publicly. Even when they do, they speak a little. This leads to frustration on the side of the teacher, in addition to the absence of any clear feedback from the students: whether they have/have not understood the lecture." (Brown 1992, p. 255) identifies that "It is argued that one of the major obstacles learner have to overcome in learning to speak is the anxiety generated over risk of blurring thing out that are wrong."

English is a global language; it is the language of commerce, technology and science for generation to come. 1.5 billion people learning English Language in the world today, although everyone knows this language. (Judy 2011, p. 13 \& 17) pointed that "there is always a problem to differentiate between written English alphabets and spoken alphabet." As Mark Twain said: "The heart of our trouble is with our foolish alphabet." According to Elfrieda H. Hiebert, Micheal L. Kamil 2005, p. 3) "Vocabulary is the knowledge of meaning of words, what complicates this definition is the fact that words come in at least two forms: oral and print. Knowledge of words also comes in at least two forms, receptive - that we can understand or recognize, and productive - the vocabulary we use when we write or speak." HARRY AYERS (2006) stated that "anxiety and depression are just two effective factors that contribute to learning difficulties or are the result of learning difficulties. The impact of persistent failure can adversely affect a pupil's self-esteem, confidence, perceived self-efficacy, attitude and motivation. When confronted by certain tasks pupils may develop anxious feelings, fearing they will fail.” (p. 4). $\mathrm{He}$ also noted that "internal and external factors can both contribute to learning failure. Internal factors include low ability, emotional and behavioral problems, medical syndromes or conditions, neurological problems, genetic influences, learning difficulties and disabilities, sensory impairment, low perceived self-efficacy, learned helplessness, fear of failure and motivational problems. External factors include inadequate or inappropriate teaching and teaching methods, lack of differentiation, inappropriate curriculum, negative teacher-learner relationships, truancy and absenteeism, and negative classroom or school environment. "(Ibid p. 38)

\subsection{Previous Studies}

\subsubsection{Previous Studies Related to Instructors}

Ali Dincer \& Savas Yesilyurt (2013) in their study Pre-Service English Teachers' Beliefs on Speaking Skills Based on Motivational Orientations showed that the findings revealed that "the subjects, whether they were intrinsically or extrinsically motivated to speak English, had negative ideas about speaking instruction in Turkey, though they all agreed that it was the most important language skill. The findings also showed that they felt incompetent in oral communication though they had different motivational orientations about speaking English. The findings are significant for understanding speaking instruction in English language classrooms from a motivational perspective and helpful for enhancing learners' speaking ability with intrinsic motivation." Eid 
Alhaisoni (2012) A Think-aloud Protocols Investigation of Saudi English Major Students 'Writing Revision Strategies in L1 (Arabic) and L2 (English) revealed that "most of the strategies were found to be used more frequently in English than in Arabic. A major similarity was that, in general, those strategies which were found to be mostly used in Arabic were also used most in English as well and vice versa. The study also concluded: The teaching of L1 writing in public schools in Saudi Arabia starts in the third grade and ends by the end of the twelfth grade. Even during the nine years of one-class a week instruction, L1 writing is regarded as a course in which no student can fail. Many teachers and students do not give writing class the attention it deserves."

\subsubsection{Previous Studies Related to Students}

Ali Dincer \& Savas Yesilyurt (2013) in their study Pre-Service English Teachers' Beliefs on Speaking Skills Based on Motivational Orientations showed that: "The findings revealed that students' ideas about the importance of speaking skills among the four language skills are diverse; this diversity is associated with the students' motivational orientations and students' feeling competent/incompetent in speaking. Also students' self-assessment about their speaking ability was generally negative and they expressed themselves as incompetent speakers. Few of them said that, compared to other students, they had a better position both in participating in speaking activities and speaking English." Eissa, Misbah and Najat (1988) in their study Problems of using English as a medium of instruction and communication at the college of science, Kuwait University concluded that: "The students had several problems in using English language as the medium of instruction. Majority of the college members (64\%) admitted that their students' English language proficiency was very low that hindered their studies in their respective subjects. The students' difficulty in comprehending their English-medium textbooks was reported by (48\%) college members, whereas (54\%) of them stated that the students faced severe problems in comprehending the content-subject lectures delivered in English without translation or using L1 to deliver the lecture content. The findings suggested that the students suffered from English language deficiency due to weak background."

\subsubsection{Previous Studies Related to Curriculum and Textbook}

Al-Saidat, Emad M. (2009) in his study English in Jordan: Attitudes and Prestige about Jordanian university students' attitude towards English as a foreign language concluded: 1. Participants are in favor of English language learning but not up to native speakers' level of fluency. 2. English language is seen as important and necessary for them but not as Arabic language; loyalty to Arabic language exists in the society represented by the participants as the native language, the official language of the country and the language of the religion. 3 . Learning English has nothing negative to do with Arabic language and Islamic religion in Jordan. 4. Participants' needs of English language are instrumental needs rather than integrative ones. 5. English in Jordan is the language of prestige, science, technology, and communication with non-native speakers of Arabic. 6. People who speak English language are superiors, more educated than others are, and have a good career future." Hadeel Adayleh (2013), in her study The Difficulties Faced by English Language and Literature Students at Mu'tah University in Mastering English Language Pronunciation concluded that: "The problem is mainly reported in issues like sound recognition, connected speech, and the relation between spelling and sounds. This is clearly noticed when examining their performance in English. For example, they fail to assign stress properly and reflect content by intonation. They may even change sound quality. Mistakes in pronunciation that hinder meaning or change it are classified as bad pronunciation."

\subsubsection{Previous Studies Related to English Language Methods and Exercises}

Ghaleb Rabab'ah (2013) study Strategies of Repair in EFL Learners' Oral Discourse revealed that: "Both German and Jordanian non-native speakers of English resort to strategies of repair in order to compensate for their lack of linguistic items or to gain time to retrieve linguistic item(s) and maintain conversation. Moreover, the results indicate that the Jordanian Arabic speaking subjects used strategies of repair more frequently, which was attributed to the fact that they produced more story events, which doubled the number of words in their oral production. Another finding was that repetition was used more frequently than self-initiated repair by both groups. The results of this study may provide some useful insights into syllabus design and English language teaching." Choudhary Z. Javid, Turki S. Al-Thubaiti \& Awwadh Uthman (2012) reported in their study Effects of English Language Proficiency on the Choice of Language Learning Strategies by Saudi English-major Undergraduates, that: "The participants with high English language proficiency use language learning strategies more frequently, it is concluded that it seems necessary to teach language learning strategies explicitly so that even the weaker students should be able to enhance English language proficiency by exploiting a wide range of suitable strategies that are appropriate to different classroom activities and learners' L2 experience." 


\subsubsection{Previous Studies Related to Teaching and Learning Environment}

Chaudhry Zahid Javid, Muhammad Umar Farooq, Malik Ajmal Gulzar (2012) in their study Saudi English-Major Undergraduates and English Teachers ' Perceptions Regarding Effective ELT in the KSA: a Comparative Study concluded that: "a. Classrooms should be more interactive. b. Classrooms need to be equipped with modern teaching resources. c. Students' English language proficiency is poor when they join Taif University. d. The students have to pass an English language proficiency test to qualify for the next academic year. e. The department should start remedial courses for the weaker students." Qashoa S. H. H. (2006) revealed in his study Motivation among Learners of English in the Secondary Schools in the Eastern Coast of the UAE, that :"Second and foreign language learners should be offered the opportunity to be motivated and fulfill their learning orientations." He also revealed that: "The UAE students have a higher degree of instrumentality than integrativeness. Contrary to the findings of other related studies, difficulties with the subject (English) aspects such as vocabulary, structures and spelling were found to be in the first place in terms of demotivating factors." Zeinab Moradi Khazaei, Ahmad Moinzadeh \& Saeed Ketabi (2012) in their study Willingness to Communicate in Iranian EFL Learners: The Effect of Class Size indicated that "Class size had a substantial effect on the students' willingness to communicate. Students were found to be more willing to communicate in small classes where they had more opportunity to practice oral skills and communicate."

\section{Research Methodology}

\subsection{Data Collection}

The study has been carried in two Colleges of Science and Arts (Alamjardah and Mahayeal) of King Khalid University in the academic year 2012-2013.

\subsection{Population of the Study}

10 Female instructors and 150 girl-students of the first and second year at English Department of colleges of Science and Arts (Alamjardah and Mahayeal) of King Khalid University were the sample of the study.

\subsection{Study Instrument}

A: 150 questionnaire papers were distributed to the students for collecting the data, 137 of the questionnaire papers were completed. The questionnaire was divided to five domains: 1. Instructors. 2. Students. 3. Curriculum and Textbook. 4. English language teaching methods and exercises. 5. Teaching and Learning environment. These domains may reflect the factors that negatively affect speaking skills at Saudi colleges for girls in the South.

B: 10 Female instructors were interviewed about the questionnaire information.

\subsection{Validity and Reliability of the Students' Questionnaire}

According to the table 1, using: (a: Cronbach's Alpha. b: Spearman \& Brown. c: One-Sample Test), it is obvious that $(0.86)$ and $(0.85)$ reflect that the validity and reliability is suitable for the study.

Table 1. Validity and reliability of the students' questionnaire

\begin{tabular}{lll}
\hline & Cronbach's Alpha & Spearman \& Brown \\
\hline Reliable & .740 & .727 \\
Validity & 0.86 & 0.85 \\
\hline
\end{tabular}

\section{Data Analysis and Discussion}

The responses generated through the questionnaire were manually coded and analyzed using SPSS version 10 . The researcher used t-test through t-distribution table to find if the result of the students' questionnaire is significant or not to predict the factors that negatively affect English language speaking skills in Saudi colleges for girls. Below are the t-distribution tables for each domain's items which will be discussed below to find the final results. 
Table 2. Factors negatively affect speaking skills at Saudi Colleges for girls in the South related to the instructors

\begin{tabular}{|c|c|c|c|c|c|c|c|}
\hline \multirow[b]{2}{*}{ Questionnaire items } & \multicolumn{5}{|c|}{ Test Value $=2$} & \multirow{2}{*}{$\begin{array}{l}\text { Reality of } \\
0.05\end{array}$} & \multirow[b]{2}{*}{ Predication } \\
\hline & Mean & $\begin{array}{l}\text { Std. } \\
\text { Deviation }\end{array}$ & $\mathrm{t}$ & df & $\begin{array}{l}\text { Sig(one } \\
\text {-tailed }\end{array}$ & & \\
\hline $\begin{array}{l}1 \text { Instructors encourage us to } \\
\text { answer in English language. }\end{array}$ & 2.62 & .686 & 10.677 & 137 & .000 & $\begin{array}{l}\text { Function } \\
\mathrm{p}<0.05\end{array}$ & Significant \\
\hline $\begin{array}{l}2 \text { Instructors let us use Arabic } \\
\text { language to express our } \\
\text { answers. }\end{array}$ & 1.80 & .919 & -2.501 & 137 & .014 & $\begin{array}{l}\text { Function } \\
\mathrm{p}<0.05\end{array}$ & Significant \\
\hline $\begin{array}{l}3 \text { Instructors only use English } \\
\text { language to communicate } \\
\text { with us inside the class. }\end{array}$ & 2.50 & .804 & 7.308 & 137 & .000 & $\begin{array}{l}\text { Function } \\
\mathrm{p}<0.05\end{array}$ & Significant \\
\hline $\begin{array}{l}4 \text { Instructors only use English } \\
\text { language to communicate } \\
\text { with us outside the class. }\end{array}$ & 1.71 & .865 & -3.938 & 137 & .000 & $\begin{array}{l}\text { Function } \\
\mathrm{p}<0.05\end{array}$ & Significant \\
\hline
\end{tabular}

Independent Sample t-test was applied to identify any significant differences in responses to the students' questionnaire. The results in the items of table (2) reveal that all items are significant which means (1) Instructors encourage the students to answer in English language and (3) Instructors only use English language to communicate with the students inside the class, but for (3) \& (4) the results show low indictors because t-value is not positive. Which means in (2) the instructors sometimes let the students use Arabic language to express their answers and in (4) Instructors often use English language to communicate with the students outside the class.

Table 3. Factors negatively affect speaking skills at Saudi Colleges for Girls in the South related to the students

\begin{tabular}{|c|c|c|c|c|c|c|c|c|}
\hline \multirow{2}{*}{\multicolumn{2}{|c|}{ Questionnaire items }} & \multicolumn{5}{|c|}{ Test Value $=2$} & \multirow{3}{*}{$\begin{array}{l}\text { Reality of } \\
0.05 \\
\text { Function } \\
p<0.05\end{array}$} & \multirow{3}{*}{$\begin{array}{l}\text { Predication } \\
\text { Significant }\end{array}$} \\
\hline & & \multirow{2}{*}{$\begin{array}{l}\text { Mean } \\
1.79\end{array}$} & \multirow{2}{*}{$\begin{array}{l}\text { Std. } \\
\text { Deviation } \\
.970\end{array}$} & \multirow{2}{*}{$\begin{array}{l}\mathrm{t} \\
-2.545\end{array}$} & \multirow{2}{*}{$\begin{array}{l}\mathrm{df} \\
137\end{array}$} & \multirow{2}{*}{$\begin{array}{l}\begin{array}{l}\text { Sig(one } \\
\text {-tailed) }\end{array} \\
.012\end{array}$} & & \\
\hline 5 & $\begin{array}{l}\text { I used to practice speaking } \\
\text { skills at secondary level. }\end{array}$ & & & & & & & \\
\hline 6 & $\begin{array}{l}\text { I speak English language } \\
\text { fluently. }\end{array}$ & 1.65 & .868 & -4.705 & 137 & .000 & $\begin{array}{l}\text { Function } \\
\mathrm{p}<0.05\end{array}$ & Significant \\
\hline 7 & $\begin{array}{l}\text { I can speak fluently but I } \\
\text { fear speaking English } \\
\text { language in public. }\end{array}$ & 1.99 & .970 & -.088 & 137 & .930 & $\begin{array}{l}\text { No function } \\
\mathrm{p}>0.05\end{array}$ & Not significant \\
\hline 8 & $\begin{array}{l}\text { My possession of English } \\
\text { vocabulary is enough to } \\
\text { speak English fluently. }\end{array}$ & 1.71 & .890 & -3.828 & 137 & .000 & $\begin{array}{l}\text { Function } \\
\mathrm{p}<0.05\end{array}$ & Significant \\
\hline 9 & $\begin{array}{l}\text { My Grammar knowledge is } \\
\text { good enough to construct } \\
\text { the sentences I want to say. }\end{array}$ & 1.90 & .898 & -1.327 & 137 & .187 & $\begin{array}{l}\text { No function } \\
p>0.05\end{array}$ & Not significant \\
\hline 10 & $\begin{array}{l}\text { I only speak English } \\
\text { Language inside the } \\
\text { lecture-room. }\end{array}$ & 1.73 & .956 & -3.296 & 137 & .001 & $\begin{array}{l}\text { Function } \\
\mathrm{p}<0.05\end{array}$ & Significant \\
\hline 11 & $\begin{array}{l}\text { I practice English speaking } \\
\text { skills in English club inside } \\
\text { the college. }\end{array}$ & 1.47 & .914 & -6.801 & 137 & .000 & $\begin{array}{l}\text { Function } \\
\mathrm{p}<0.05\end{array}$ & Significant \\
\hline 12 & $\begin{array}{l}\text { I can make a phone } \\
\text { conversation in English. }\end{array}$ & 1.90 & .930 & -1.281 & 137 & .202 & $\begin{array}{l}\text { No function } \\
p>0.05\end{array}$ & Not significant \\
\hline 13 & $\begin{array}{l}\text { I can make presentation in } \\
\text { English Language. }\end{array}$ & 2.02 & .908 & .281 & 137 & .779 & $\begin{array}{l}\text { No function } \\
p>0.05\end{array}$ & Not significant \\
\hline 14 & $\begin{array}{l}\text { I can express my point of } \\
\text { view in English without } \\
\text { Arabic translation. }\end{array}$ & 1.90 & .907 & -1.315 & 137 & .191 & $\begin{array}{l}\text { No function } \\
\mathrm{p}>0.05\end{array}$ & Not significant \\
\hline
\end{tabular}


After applying the independent sample t-test to identify any significant differences in the responses to the students' questionnaire to find factors negatively affect speaking skills at Saudi Colleges for girls in the South, the responses to the items of table (3) differed, that the items $(7,9,12,13 \& 14)$ were not significant, which means 7. Students can't speak fluently and they fear speaking English language in public. 9. Students Grammar knowledge is not enough to construct the sentences they want to say. 12. Students can't make a phone conversation in English. 13. Students can't make presentation in English Language. 14. Students can't express their point of view in English without Arabic translation. While items (5, 6, 8, 10 \& 11) results were significant this reveals the statements of these items. 5. Students used to practice speaking skills at secondary level. 6 . Students speak English language fluently. 8. Students' possession of English vocabulary is enough to speak English fluently. 10. Students only speak English Language inside the lecture - room. 11. Students don't practice English speaking skills in English club inside the college. Items (7, 9, 10,11, 12, 13 \& 14) can be indicators for the factors that negatively affect speaking skills at Saudi Colleges for girls in the South related to the students.

Table 4. Factors negatively affect speaking skills at Saudi Colleges for girls in the South related to the curriculum and textbook

\begin{tabular}{|c|c|c|c|c|c|c|c|c|}
\hline \multirow{2}{*}{\multicolumn{2}{|c|}{ Questionnaire items }} & \multicolumn{5}{|c|}{ Test Value $=2$} & \multirow{2}{*}{$\begin{array}{l}\text { Reality of } \\
0.05\end{array}$} & \multirow[b]{2}{*}{ Predication } \\
\hline & & Mean & $\begin{array}{l}\text { Std. } \\
\text { Deviation }\end{array}$ & $\mathrm{t}$ & $\mathrm{df}$ & $\begin{array}{l}\text { Sig(one } \\
\text {-tailed) }\end{array}$ & & \\
\hline 15 & $\begin{array}{l}\text { All students have text book } \\
\text { concern Listening and } \\
\text { Speaking skills class. }\end{array}$ & 2.36 & .957 & 4.356 & 137 & .000 & $\begin{array}{l}\text { Function } \\
\mathrm{p}<0.05\end{array}$ & Significant \\
\hline 16 & $\begin{array}{l}\text { Our Curriculum of Listening } \\
\text { and Speaking contains enough } \\
\text { exercises for speaking skills. }\end{array}$ & 1.67 & .954 & -4.105 & 137 & .000 & $\begin{array}{l}\text { Function } \\
\mathrm{p}<0.05\end{array}$ & Significant \\
\hline 17 & $\begin{array}{l}\text { The exercises in my text book } \\
\text { strength my speaking skills. }\end{array}$ & 1.88 & 1.011 & -1.347 & 137 & .180 & $\begin{array}{l}\text { No function } \\
p>0.05\end{array}$ & Significant \\
\hline 18 & $\begin{array}{l}\text { There are many speaking } \\
\text { exercises in my book to be } \\
\text { practiced inside and outside } \\
\text { the class. }\end{array}$ & 1.72 & 1.016 & -3.183 & 137 & .002 & $\begin{array}{l}\text { Function } \\
\mathrm{p}<0.05\end{array}$ & Significant \\
\hline
\end{tabular}

Table (4) contains the data generated through independent sample t-test and the table shows that all items are significant but items $(16,17 \& 18)$ in low value which can be taken as indicators to the factors negatively affect speaking skills at Saudi Colleges for girls in the South related to the curriculum and textbook, which all agreed that the speaking exercises are not enough to develop speaking proficiency.

Table 5. Factors negatively affect speaking skills at Saudi Colleges for girls in the South related to the English language methods and exercises

\begin{tabular}{|c|c|c|c|c|c|c|c|c|}
\hline \multirow{2}{*}{\multicolumn{2}{|c|}{ Questionnaire items }} & \multicolumn{5}{|c|}{ Test Value $=2$} & \multirow{2}{*}{$\begin{array}{l}\text { Reality of } \\
0.05\end{array}$} & \multirow[b]{2}{*}{ Predication } \\
\hline & & \multirow{2}{*}{$\begin{array}{l}\text { Mean } \\
2.25\end{array}$} & \multirow{2}{*}{$\begin{array}{l}\text { Std. } \\
\text { Deviation } \\
1.038\end{array}$} & \multirow{2}{*}{$\begin{array}{l}\mathrm{t} \\
2.788\end{array}$} & \multirow{2}{*}{$\begin{array}{l}\mathrm{df} \\
137\end{array}$} & \multirow{2}{*}{$\begin{array}{l}\text { Sig(one } \\
\text {-tailed) } \\
.006\end{array}$} & & \\
\hline 19 & $\begin{array}{l}\text { Instructors only use English } \\
\text { language in teaching. }\end{array}$ & & & & & & $\begin{array}{l}\text { Function } \\
\mathrm{p}<0.05\end{array}$ & Significant \\
\hline 20 & $\begin{array}{l}\text { Instructors use mixture of } \\
\text { English language and Arabic } \\
\text { language in teaching. }\end{array}$ & 1.93 & 1.027 & -.746 & 137 & .457 & $\begin{array}{l}\text { No function } \\
p>0.05\end{array}$ & Not significant \\
\hline 21 & $\begin{array}{l}\text { Instructors use different } \\
\text { strategies like body language, } \\
\text { intonation etc. to teach } \\
\text { speaking skills. }\end{array}$ & 1.83 & 1.017 & -2.008 & 137 & .047 & $\begin{array}{l}\text { Function } \\
\mathrm{p}<0.05\end{array}$ & Significant \\
\hline 22 & $\begin{array}{l}\text { Instructors ask us to make } \\
\text { presentation in English } \\
\text { language. }\end{array}$ & 2.01 & 1.070 & .080 & 137 & .937 & $\begin{array}{l}\text { No function } \\
p>0.05\end{array}$ & Not significant \\
\hline 23 & Instructors use debatable topic & 1.70 & 1.044 & -3.426 & 137 & .001 & Function & Significant \\
\hline
\end{tabular}


to encourage discussions inside the class.

24 Instructors encourage us to express our point of view in English.

25 Instructors don't let us use Arabic language inside the class.

26 Instructors make us do role-play to practice speaking skills.

27 We have three hours a week for listening and speaking class.

28 The time devoted to speaking English language is enough.

29 More exercises are given to speaking skills than listening skills.

30 More time is given to practice speaking than to practice listening.

$\mathrm{p}<0.05$

$\begin{array}{llllll}1.94 & 1.052 & -648 & 137 & .518 & \begin{array}{l}\text { No function Not significant } \\ \mathrm{p}>0.05\end{array}\end{array}$

$\begin{array}{llllll}1.87 & 1.080 & -1.419 & 137 & .158 & \begin{array}{l}\text { No function Not significant } \\ \mathrm{p}>0.05\end{array}\end{array}$

$\begin{array}{llllll}1.88 & 1.014 & -1.427 & 137 & .156 & \text { No function Not significant }\end{array}$ $\mathrm{p}>0.05$

$\begin{array}{lllllll}2.27 & 1.071 & 2.941 & 137 & .004 & \begin{array}{l}\text { Function } \\ \mathrm{p}<0.05\end{array} & \text { Significant }\end{array}$

$\begin{array}{llllllll}1.99 & 1.046 & -.163 & 137 & .871 & \begin{array}{l}\text { No function } \\ \mathrm{p}>0.05\end{array} & \text { Not significant } \\ 1.75 & .997 & -2.989 & 137 & .003 & \begin{array}{l}\text { Function } \\ \mathrm{p}<0.05\end{array} & \text { Significant } \\ 1.65 & 1.030 & -3.968 & 137 & .000 & \begin{array}{l}\text { Function } \\ \mathrm{p}<0.05\end{array} & \text { Significant }\end{array}$

Independent sample t-test was applied to identify any significant differences in responses to the students' questionnaire. The results to items of table (5) reveal that all items $(20,22,24,25,26 \& 28)$ were not significant which means: 20. Instructors don't use mixture of English language and Arabic language in teaching. 22. Instructors don't ask the students to make presentation in English language. 24. Instructors don't encourage the students to express their point of view in English. 25. Instructors let the students use Arabic language inside the class. 26. Instructors don't make the students do role-play to practice speaking skills. 28. The time devoted to speaking English language is not enough. While items (19 \& 27) were significant in a high value and items which means: 19. Instructors only use English language in teaching. 27. The students have three hours a week for both listening and speaking class. $(21,23,29,30)$ were significant but in low value. 21 . Instructors rarely use different strategies like body language, intonation ......etc. to teach speaking skills. 23. Instructors rarely use debatable topic to encourage discussions inside the class. 29. Rarely more exercises are given to speaking skills than listening skills. 30. Rarely more time is given to practice speaking than to practice listening. Using Arabic language, ineffective teaching strategies and motivation, poor speaking practice, and wrong immoral distribution of time between listening and speaking can be indicators for factors negatively affect speaking skills at Saudi Colleges for girls in the South related to the English language methods and exercises.

Table 6. Factors negatively affect speaking skills at Saudi Colleges for girls in the South related to the teaching and learning environment

\begin{tabular}{lllllllll}
\hline & & \multicolumn{2}{l}{ Test Value $=2$} & & & \\
Questionnaire items & Mean & $\begin{array}{l}\text { Std. } \\
\text { Deviation }\end{array}$ & $\mathrm{t}$ & $\mathrm{df}$ & $\begin{array}{l}\text { Sig(one } \\
\text {-tailed })\end{array}$ & $\begin{array}{l}\text { Reality of } \\
0.05\end{array}$ & Predication \\
\hline 31 & $\begin{array}{l}\text { In my class there are } \\
30 \text { students. }\end{array}$ & 2.15 & 1.053 & 1.698 & 137 & .092 & $\begin{array}{l}\text { No function } \\
\mathrm{p}>0.05\end{array}$ & Not significant \\
32 & $\begin{array}{l}\text { We listen to a CD as a } \\
\text { model for speaking } \\
\text { practice. }\end{array}$ & 1.78 & 1.030 & -2.478 & 137 & .014 & $\begin{array}{l}\text { Function } \\
\mathrm{p}<0.05\end{array}$ & Significant \\
33 & $\begin{array}{l}\text { We learn listening and } \\
\text { speaking in the } \\
\text { language lab. }\end{array}$ & 1.89 & 1.072 & -1.191 & 137 & .236 & $\begin{array}{l}\text { No function } \\
\mathrm{p}>0.05\end{array}$ & Not significant \\
\hline
\end{tabular}


Table (6) contains the data generated through independent Sample t-test and the table results show that item (31, 33) were not significant which means: In the class there are more than 30 students. Students don't learn listening and speaking in the language lab, and item (32) was significant in a low value which means: Students rarely listen to a $\mathrm{CD}$ as a model for speaking practice. These results can be indicators for factor negatively affects speaking skills at Saudi Colleges for girls in the South related to the teaching and learning environment.

\section{Results and Discussions}

\subsection{Discussion of Domain (1) Results}

After doing the statistical procedure and discussion and corresponding it to the instructors' interviews to find factors affect speaking skills at Saudi Colleges for girls in the South related to the instructors, the results were as follows: 1. Instructors encourage the students to answer in English language. 2. Instructors only use English language to communicate with the students inside the class. 3. Instructors let the students use Arabic some times to express what they can't in English. These results are similar to those found by (Ali Dincer \& Savas Yesilyurt 2013), and (Eid Alhaisoni 2008), the results also agreed with what (Harry Ayers, 2009) mentioned in his book p. 38. All these finding show how students' confidence affects speaking proficiency skills.

\subsection{Discussion of Domain (2) Results}

The statistical procedure and discussion corresponded to the instructors' interviews about factors affect speaking skills at Saudi Colleges for girls in the South related to the students shown that: 1 . Students can't speak fluently. 2. Students fear speaking English language in public. 3. Students' grammar knowledge is not enough to construct the sentences they want to say. 4. Students can't make a phone conversation. 5. Students can't make presentation in English. 6. Students can't express their point of view in English without Arabic translation. 7. Students use Arabic language in the class. The same results found by (Ali Diner \& Savas Yesilyurt 2013), and (Eissa, Misbahand Najat 1988) the results above can be taken as factors affect speaking skills.

\subsection{Discussion of Domain (3) Results}

Statistical procedure and discussion corresponded to the instructors' interviews about factors affect speaking skills at Saudi Colleges for girls in the South related curriculum and textbook shown that: 1. Curriculum of listening and speaking does not contain enough exercises for speaking skills. 2. The exercises in text book strength listening skills more than speaking skills. 3. There aren't enough speaking exercises in the text book to be practiced inside and outside the class. The finding of this study agrees with the second finding of (Al-Saidat, Emad M. 2009) study and can be reasoned by the finding of (Hadeel Adayleh 2013) study.

\subsection{Discussion of Domain (4) Results}

After doing the statistical procedure and discussion and corresponding it to the instructors interviews to find factors affect speaking skills at Saudi Colleges for girls in the South related to the English language methods and exercises the results shown: 1. Instructor don't ask the students to make presentation in English language. 2. Instructors don't encourage the students to express their point of view in English and let them use Arabic in the class. 3. No role-play practiced by the students to develop speaking skills. 4 . The time devoted to speaking English language is not enough as the students have three hours a week for both listening and speaking class and most of the hours are devoted to listening exercises and practice. 5. No debatable topics are used to encourage discussions inside the class. 6 . Instructors rarely use different strategies like body language, intonation .......etc. to teach speaking skills. The same results found in (Ghaleb Rabab'ah 2013) and (Choudhary Z. Javid) and (Turki S. Al-thubaiti) and (Awwadh Uthman 2012) and (Hadeel Adayleh 2013) studies.

\subsection{Discussion of Domain (5) Results}

The statistical procedure and discussion corresponded to the instructors' interviews about factors affect speaking skills at Saudi Colleges for girls in the South related to the teaching and learning environment shown that: 1 . Students don't learn listening and speaking in the language lab. 2. Students rarely listen to a CD as a model for speaking practice. 3. There are more than 30 students in the class. Many studies like (Chaudhry Zahid Javid, Muhammad Umar Farooq, Malik Ajmal Gulzar 2012), (Qashoa, S. H. H 2006) and (Zeinab Moradi Khazaei \& Ahmad Moin Zadeh, \& Saeed Ketabi 2012) studies came out with similar results.

\section{Conclusion of the Finding}

The main conclusion of this study domains' results that affect speaking skills at Saudi Colleges for girls in the South are: 1. Students background of English is weak. 2. Instructors let the students to use Arabic some times to express what they can't do in English may hinder the students English speaking skills proficiency as they depend partly in Arabic. 3. The students fear speaking English language in public and can't make a phone conversation, 
presentation in English, or express their point of view in English without Arabic translation. 4. Curriculum of listening and speaking does not contain enough exercises for speaking skills and most of the exercises concentrate on listening more than speaking. 5. Instructors don't use strategies that help the students develop speaking such as: role-play, debates, presentation assignment. 6. More time (out of three hours a week) is devoted to practice listening skills rather than speaking skills. 7. Instructors don't teach listening and speaking course in the lab. 8. Students rarely listen to a CD as a model for speaking practice as strategy for learning. 9. Students' number in the class hinders speaking skills.

\section{Recommendations}

1. Instructors must not let the students use Arabic in English lessons. 2. Instructors should motivate students to speak, and overcome their fear of speaking by using different strategies such as: cultural debatable topic, discussions, role- play in the classroom. 3. Instructors should encourage the students to make presentation in English to develop speaking skills and students' confidence. 4. Instructors should teach listening and speaking courses in the labs. 5. Increase the time of Listening and Speaking course to six hours instead of three to help students practice speaking and give them better opportunity to develop speaking skills in their class, as it is the only place where they practice English skills. 6. Activate English club and societies inside the colleges as students' activity to develop speaking skills. 7. Decrease the number of students in listening and speaking class (not to exceed 30 students).

\section{References}

Ali Dincer, \& Savas Yesilyurt. (2013). Pre-Service English Teachers' Beliefs on Speaking Skills Based on Motivational Orientations. English Language Teaching, 6(7), 88-95. http://dx.doi.org/10.5539/elt.v6n7p88

Al-Saidat, Emad M. (2009). English in Jordan: Attitudes and prestige. Indian Journal of Applied Linguistics, 35(2), 155-167. http://eric.ed.gov/?id=EJ865572

Chaudhry Zahid Javid, Muhammad Umar Farooq, \& Malik Ajmal Gulzar. (2012). In their study Saudi English-Major Undergraduates and English Teachers' Perceptions Regarding Effective ELT in the KSA: A Comparative Study. European Journal of Scientific Research, 85(1), 55-70. http://www.europeanjournalofscientificresearch.com/ISSUES/EJSR_85_1.htm

Choudhary Z. Javid, Turki S. Al-thubaiti, \& Awwadh Uthman. (2013). Effects of English Language Proficiency on the Choice of Language Learning Strategies by Saudi English-major Undergraduates. English Language Teaching, 6(1), 35-47. http://dx.doi.org/10.5539/elt.v6n1p35

Eid Alhaisoni. (2012). Think-aloud Protocols Investigation of Saudi English Major Students' Writing Revision Strategies in L1 (Arabic) and L2 (English). English Language Teaching, 5(9), 144-154. http://dx.doi.org/10.5539/elt.v5n9p144

Eissa, A. Misbah, \& A. Najat. (1988). In their study: "Problems of Using English as a Medium of Instruction and Communication at the College of Science, Kuwait University". Educational Journal, 4(15), 47-94.

Elfrieda H. Hiebert, \& Micheal L. Kamil. (2005). Teaching and Learning Vocabulary, Brining Research to Practice. Lawrence Erlbaum Associates Inc, New Jersey.

Fahad Hamad Aljumah. (2011). Developing Saudi EFL Students' Oral Skills: An Integrative Approach. English Language Teaching, 4(3), 84-89. http://dx.doi.org /10.5539/elt.v4n3p84

Ghaleb Rabab'ah. (2013). Strategies of Repair in EFL Learners' Oral Discourse. English Language Teaching, 6(6), 123-131. http://dx.doi.org/10.5539/elt.v6n6p123

H. Douglas Brown. (1994). Teaching by Principles: An Integrative Approach to Language Pedagogy. Prentice -hall Regents, New Jersey.

Hadeel Adayleh. (2013). The Difficulties Faced by English Language and Literature Students at Mu'tah University in Mastering English Language Pronunciation. European Journal of social science, 38(2) 205-209. http://www.europeanjournalofsocialsciences.com/ISSUES/EJSS_38_2.htm

HARRY AYERS. (2006). An A to Z Practical Guide to Learning Difficulties. David Fulton Publishers, New York.

Judith Munat. English as a Vehicular Language: A Case of Globalization or Linguistic Imperialism. University of Pisa. $\quad$ Retrieved from http://www.stm.unipi.it/programmasocrates/cliohnet/books/language2/11_Munat.pdf

Judy Thompson. (2011). English is Stupid. Thompson Language center. 
Qashoa S. H. H. (2006). Motivation among Learners of English in the Secondary Schools in the Eastern Coast of the UAE. An MA Dissertation submitted to institute of Education, British University in Dubai, UAE. Retrieved from http://www.asian-efl-journal.com/thesis_Sulaiman_Hasan_Qashoa.pdf

Cody. (2011). The Art of Writing \& Speaking: The English Language Word Study. Andrew Hodson.

The 4 Language skills - English Club. Retrieved from http://www.englishclub.com/learn-english/language-skills.htm

The quote garden - quotes - saying, quotations verses. Retrieved from http://www.quotegarden.com/index.html

Wattereson, M. (2008). Repair of non-understanding in English in international communication. World Englishes, 27, 378-406. http://onlinelibrary.wiley.com/doi/10.1111/j.1467-971X.2008.00574.x/abstract

Zeinab Moradi Khazaei, Ahmad Moin Zadeh, \& Saeed Ketabi. (2012). Willingness to Communicate in Iranian EFL Learners: The Effect of Class Size. English Language Teaching, 5(11), 181-187. http://dx.doi.org/10.5539/elt.v5n11p181

\section{Appendix}

Students' Questionnaire

Dear students,

This questionnaire is designed to obtain data on-going titled:

Factors Negatively Affect Speaking Skills at Saudi Colleges for Girls in the South

Please note that any information given here is for research purpose only, and will be treated confidentially.

I'll be grateful for your anticipated co-operation.

Dr. Mona Mustafa Abdulaziz Hamad

King Khalid University

College of Science and Arts for Girls Almajardah

English Department

Students' Questionnaire

Instructions:

1. Please read each of the following statements carefully and put ( _ ) in the column (box) of the option which best describes your opinion.

Domain (1) Factors negatively affect speaking skills at Saudi Colleges for girls in the south related to the instructors.

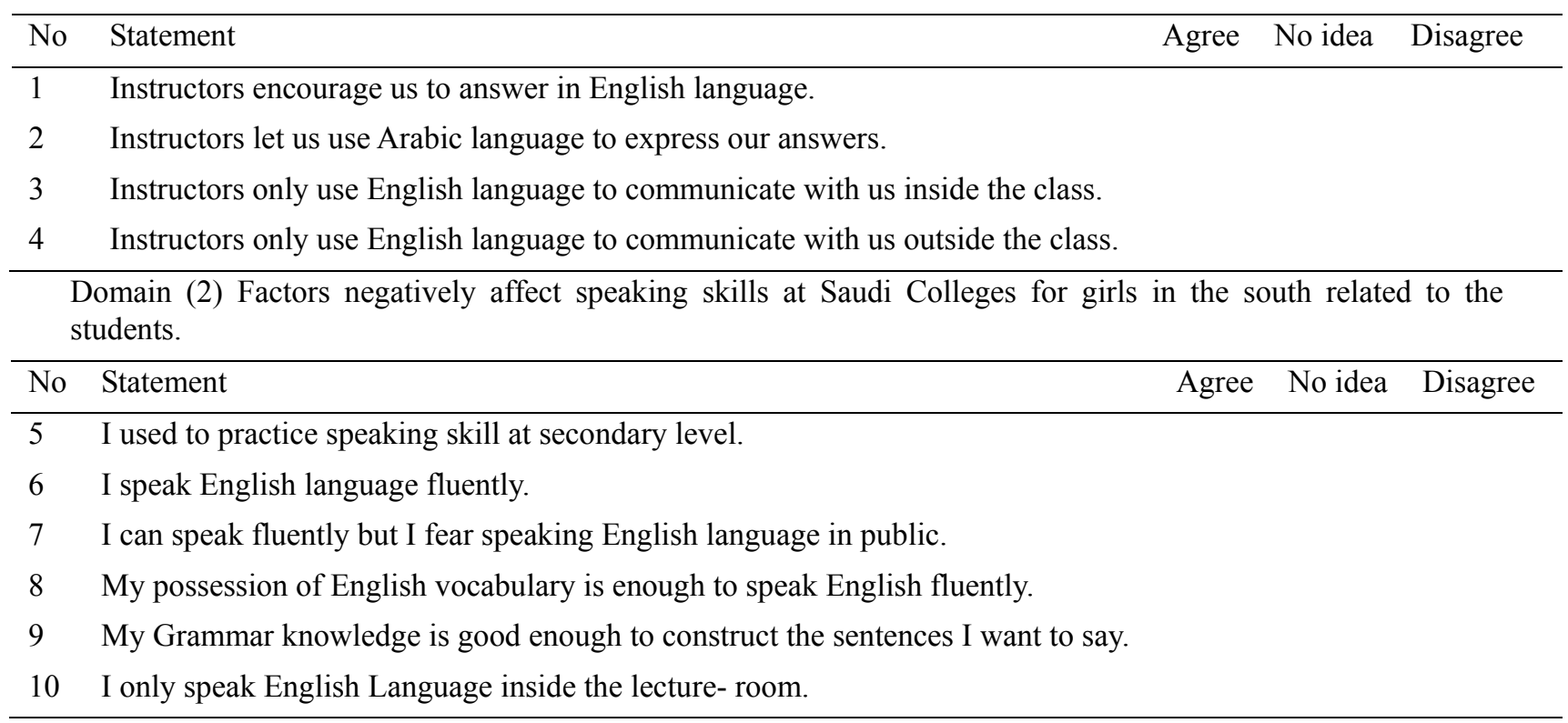


11 I practice English speaking skill in English club inside the college.

12 I can make a phone conversation in English.

13 I can make presentation in English language.

14 I can express my point of view in English without Arabic translation.

Domain (3) Factors negatively affect speaking skills at Saudi Colleges for girls in the South related to the curriculum and textbook.

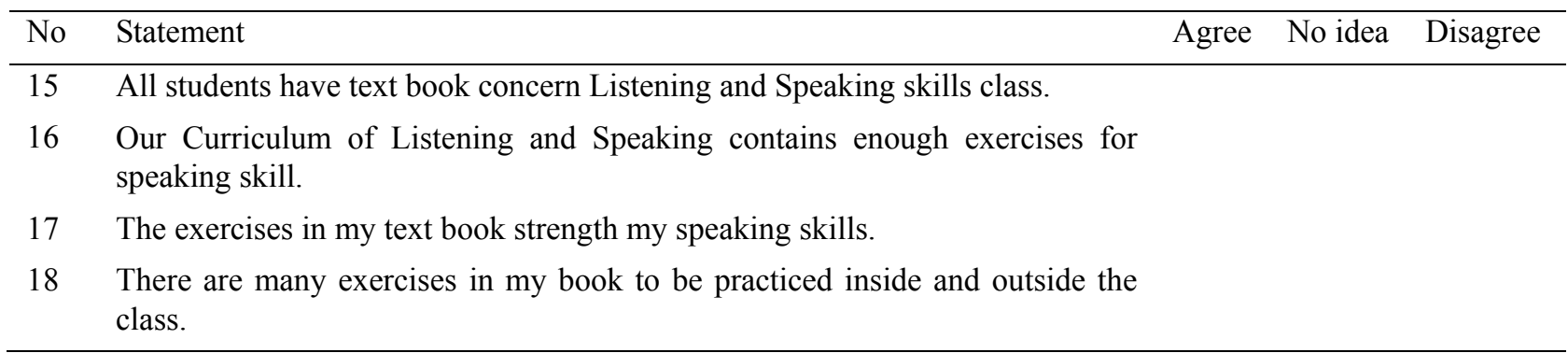

Domain (4) Factors negatively affect speaking skills at Saudi Colleges for girls in the South related to the English language teaching methods and exercises.

\begin{tabular}{|c|c|c|c|c|}
\hline No & Statement & Agree & No idea & Disagree \\
\hline 19 & Instructors only use English language in teaching. & & & \\
\hline 20 & $\begin{array}{l}\text { Instructors use mixture of English language and Arabic language in } \\
\text { teaching. }\end{array}$ & & & \\
\hline 21 & $\begin{array}{l}\text { Lecturers use different strategies like body language, intonation .......etc. } \\
\text { to teach speaking skills. }\end{array}$ & & & \\
\hline 22 & Instructors ask us to make presentation in English language. & & & \\
\hline 23 & Instructors use debatable topic to encourage discussions inside the class. & & & \\
\hline 24 & Instructors encourage us to express our point of view in English. & & & \\
\hline 25 & Instructors don't let us use Arabic language inside the class. & & & \\
\hline 26 & Instructors make us do role-play to practice speaking skills. & & & \\
\hline 27 & We have three hours a week for listening and speaking class. & & & \\
\hline 28 & The time devoted to speaking English language is enough. & & & \\
\hline 29 & More exercises are given to speaking skills than listening skills. & & & \\
\hline 30 & More time is given to practice speaking than to practice listening. & & & \\
\hline
\end{tabular}

Domain (5) Factors negatively affect speaking skills at Saudi Colleges for girls in the South related to the teaching and learning environment.

\begin{tabular}{lllll}
\hline No & Statement & Agree & No idea & Disagree \\
\hline 31 & In my class there are 30 students. & & & \\
32 & We listen to a CD as a model for speaking practice. & & & \\
33 & We learn listening and speaking in the language lab. & & & \\
\hline
\end{tabular}

\section{Copyrights}

Copyright for this article is retained by the author(s), with first publication rights granted to the journal.

This is an open-access article distributed under the terms and conditions of the Creative Commons Attribution license (http://creativecommons.org/licenses/by/3.0/). 